\title{
Kemampuan berpikir kreatif matematis dalam penyelesaian soal open-ended jenis PISA berdasarkan level sekolah
}

\author{
Evie Dwy Wahyu Arista ${ }^{1 *}$, Ali Mahmudi ${ }^{2}$ \\ ${ }^{1}$ Prodi Pendidikan Matematika, Program Pascasarjana, Universitas Negeri Yogyakarta, Yogyakarta, Indonesia \\ 2 Jurusan Pendidikan Matematika, Universitas Negeri Yogyakarta, Yogyakarta, Indonesia \\ * Corresponding Author. E-mail: aristaevie@gmail.com
}

\begin{tabular}{ll}
\hline \multicolumn{1}{c}{ ARTICLE INFO } & \multicolumn{1}{c}{ ABSTRACT } \\
\hline Article History: & Penelitian ini bertujuan untuk mendeskripsikan kemampuan berpikir kreatif matematis siswa \\
Received: 22 Sept. 2020 & dalam menyelesaikan soal open-ended jenis PISA ditinjau dari level sekolah. Jenis penelitian ini \\
Revised: 5 Oct. 2020 & adalah penelitian survei dengan sampel penelitian adalah siswa kelas X SMA $(n=260)$ di Kabu- \\
Accepted: 02 Nov. 2020 & paten Lampung Timur dengan level sekolah tinggi $(k=5)$, sedang $(k=3)$ dan rendah $(k=2)$ ber- \\
& dasarkan akreditasi. Sampel penelitian ditentukan dengan stratified proporsional random sam- \\
Keywords: & pling. Instrumen yang digunakan berupa tes kemampuan berpikir kreatif jenis soal open-ended \\
Kemampuan berpikir & PISA yang terdiri atas enam butir soal uraian dan pedoman wawancara. Instrumen tes yang \\
kreatif matematis, & digunakan telah dilakukan validasi isi oleh tiga orang ahli dengan rata-rata hasil validasi berka- \\
PISA, Soal open-ended, & tegori baik. Hasil penelitian menunjukkan bahwa kemampuan berpikir kreatif matematis siswa \\
Mathematical creative & dalam menyelesaikan soal open-ended jenis PISA pada sekolah level tinggi berada pada kategori \\
thinking ability, & cukup, pada sekolah level sedang berada pada kategori kurang, sedangkan pada sekolah level \\
Open-ended problems & rendah berada pada kategori cukup.
\end{tabular}

This research aimed to describe students' mathematical creative thinking ability in solving openended problems of PISA type based on the school level. The research was a survey with the sample was grade-ten students $(n=260)$ of senior high school with categories of the high $(k=5)$, medium ( $k=3)$, and low school $(k=2)$ based on their accreditation in the district of Lampung Timur, Indonesia. We used stratified proportional random sampling to determine the sample. The instruments used in this research consisted of a creative thinking ability test with six constructed response items and interview guidelines. Three experts had validated the instrument of a test, and it was proved to be valid in terms of content with a good category. We analyzed the collected data based on the indicator of creative thinking ability. The result showed that students' mathematical creative thinking ability to solve open-ended problem PISA type at high-level schools was in the moderate category, at medium-level schools was in the poor category, while at low-level schools in the moderate category.

This is an open access article under the CC-BY-SA license

\section{How to Cite:}

Arista, E. D. W., \& Mahmudi, A. (2020). Kemampuan berpikir kreatif matematis dalam penyelesaian soal open-ended jenis PISA berdasarkan level sekolah. Pythagoras: Jurnal Pendidikan Matematika, 15(1), 87-99. https://doi.org/10.21831/pg.v15i1.34606

https://doi.org/10.21831/pg.v15i1.34606

\section{PENDAHULUAN}

Potensi siswa yang harus dikembangkan dalam pendidikan salah satunya adalah kemampuan berpikir kreatif. Kemampuan berpikir kreatif yang disebut juga kreativitas merupakan aktivitas kognitif atau proses berpikir untuk menghasilkan gagasan yang bersifat baru dan berguna (Apino, 2016; Suharnan, 2005). Kreativitas mengarah pada kemampuan seseorang untuk membuat sesuatu dalam bentuk ide, langkah, atau produk (Sudarma, 2013). Kreativitas memiliki kedudukan yang penting dalam hal mendukung terciptanya temuan atau inovasi pada produk dan jasa (Trilling \& Fadel, 2009). Ketika dikaitkan dengan matematika, kemampuan berpikir kreatif atau kreativitas tersebut dikenal dengan istilah kemampuan berpikir kreatif matematis. Kemampuan berpikir kreatif matematis merupakan kemampuan dalam memecahkan masalah matematika untuk mengembangkan berpikir dalam struk- 
tur dengan mempertimbangkan sifat disiplin logika dan konsep yang dihasilkan untuk mengintegrasikan ide pokok dalam matematika (Sanders, 2016). Kemampuan berpikir kreatif, termasuk berpikir kreatif matematis, merupakan kemampuan yang sangat penting dalam dunia kerja (Mahmudi \& Sumarmo, 2011) dan dalam menghadapi kemajuan ilmu pengetahuan dan teknologi yang terjadi saat ini atau bahkan di masa mendatang. Mengingat pentingnya kreativitas atau kemampuan berpikir kreatif, berbagai upaya dalam bidang pendidikan telah dilakukan oleh pemerintah dalam rangka mengembangkan kemampuan tersebut yang salah satunya adalah melalui penerapan Kurikulum 2013 dengan empat belas prinsip pembelajaran yang ditetapkan. Salah satu prinsip pembelajarannya tersebut adalah memfasilitasi diproduksinya solusi atau jawaban yang kebenarannya bersifat multi dimensi (Kemendikbud, 2016a).

Beberapa ahli telah mengungkapkan pendapatnya mengenai karakteristik dari orangyang kreatif. Orang yang kreatif memiliki kemampuan fleksibilitas yang baik, mudah berkomunikasi, memiliki intelektual dengan rasa keingintahuan, dan punya rasa kebebasan (Gomez, 2007). Selain itu, dalam konteks pendidikan, menurut Brookhart (2010) seorang siswa dapat dikatakan memiliki kemampuan berpikir kreatif jika siswa tersebut memiliki kemampuan mengenal secara mendalam suatu dasar pengetahuan dan memiliki kemauan dalam belajar untuk menyelesaikan masalah yang bersifat baru. Selain itu, siswa tersebut juga terbuka terhadap ide baru dan secara aktif berusaha mencari hal-hal yang dibutuhkan untuk menyelesaikan setiap soal dan permasalahan yang diberikan. Lebih lanjut, siswa tersebut juga mencari cara untuk mengatur dan menata ide-ide ke dalam kategori yang berbeda dan mengevaluasinya, menggunakan metode trial and error ketika ragu dalam menyelesaikan soal atau permasalahan yang ada, dan menjadikan suatu kesalahan sebagai kesempatan untuk belajar. Adapun secara lebih spesifik, siswa yang memiliki kemampuan berpikir kreatif matematis yang baik memiliki karakteristik yang di antaranya adalah memahami dengan baik masalah yang dihadapi, mampu menggunakan pengetahuan yang dimilikinya secara sistematis dan koheren untuk memperoleh solusi atas masalah yang dihadapinya, dan mampu menyajikan pendekatan atau cara yang beragam untuk menemukan solusi (Rochmad et al., 2018). Dengan demikian, orang yang memiliki kemampuan berpikir kreatif dapat dicirikan dari rasa keingintahuan yang dimilikinya dan kemampuannya dalam mengeksplorasi beragam pendekatan, cara, atau metode untuk menyelesaikan suatu masalah yang bersifat baru.

Untuk menilai sejauh mana kemampuan berpikir kreatif matematis siswa, diperlukan indikator. Indikator dari kemampuan tersebut terdiri atas fluency yang menunjukkan banyaknya respons atau ide yang diberikan untuk menyelesaikan suatu masalah, flexibility yang menunjukkan kemampuan dalam melakukan penyesuaian pengetahuan atau keterampilan yang dimilikinya ke situasi yang baru, originality yang menunjukkan kemampuan dalam memberikan respons atau ide yang dibuat oleh kurang dari $10 \%$ dari jumlah siswa yang ada, dan sensitivity yang menunjukkan kemampuan dalam memprediksi konsekuensi yang mungkin ditimbulkan dari pengerjaan soal dan mendeteksi kesalahan (Kitto et al., 1994). Selain itu, ada versi lain terkait indikator dari kemampuan berpikir kreatif tersebut, di mana indikator sensitivity diganti dengan elaboration. Elaboration menunjukkan kemampuan dalam membuat interpretasi pada ide atau penyelesaian masalah secara detail (Fard et al., 2014). Pada penelitian ini, kemampuan berpikir kreatif matematis siswa dinilai berdasarkan indikator fluency, flexibility, originality, dan elaboration. Fluency di sini merujuk pada kemampuan menyelesaikan masalah yang disertai dengan banyak jawaban, flexibility merujuk pada kemampuan memberikan strategi yang jelas dan baik dalam menyelesaikan masalah, originality merujuk pada kemampuan memerikan ide yang baru atau unik dalam menyelesaikan masalah, dan elaboration merujuk pada kemampuan memerinci detail suatu masalah atau objek menggunakan berbagai macam representasi matematika.

Mengingat kemampuan berpikir kreatif matematis penting untuk dikembangkan oleh siswa, guru berupaya untuk memfasilitasi siswa mereka dalam mengembangkan kemampuan tersebut, salah satunya adalah dengan menerapkan pendekatan pembelajaran open-ended. Ini ditunjukkan oleh Noer (2011) yang meneliti kemampuan berpikir kreatif matematis menggunakan pendekatan open-ended di salah satu kota daerah Lampung dengan hasil bahwa siswa dengan level sekolah tinggi dan sedang mendapatkan peningkatan yang cukup signifikan pada kemampuan berpikir kreatif matematisnya. Ciri khas dari dari pendekatan open-ended adalah digunakannya masalah yang bersifat open-ended. Hashimoto (1997) menyebut masalah open-ended sebagai masalah yang dapat memberikan pengalaman kepada siswa untuk mencari sesuatu yang baru melalui sebuah proses. Pendapat lain mengatakan bahwa masalah open-ended merupakan masalah yang memiliki banyak solusi (Mihajlović \& Dejić, 2015). Pada matematika, masalah open-ended tersebut merupakan bagian dari soal yang tidak rutin diberikan kepada siswa. Menurut Rhosyida dan Jailani (2014), dasar keterbukaan (openness) dari open-ended dapat 
diklasifikasikan ke dalam tiga tipe, yaitu (1) prosesnya terbuka (process is open), maksudnya adalah tipe soal yang diberikan mempunyai banyak cara penyelesaian yang benar (2) hasil akhir yang terbuka (end product are open), maksudnya tipe soal yang diberikan mempunyai jawaban benar yang banyak (multiple), dan (3) cara pengembang lanjutannya terbuka (ways to develop are open). Melalui masalah open-ended, siswa diharapkan untuk menjelaskan atau melakukan justifikasi pada strategi penyelesaian masalah yang digunakannya atau solusi yang diperolehnya (Pelfrey, 2000).

Masalah terbuka juga merupakan suatu soal dengan konteks matematika dalam dunia nyata atau kehidupan sehari-hari $(\mathrm{Wu}, 1994)$. Open-ended juga menggunakan tugas secara kontekstual tertentu yang juga terdapat dalam tes level internasional yakni PISA (Programme for International Student Assessment). Soal pemecahan masalah PISA diberikan kepada anak dengan anak kisaran umur 15 tahun (IX SMP atau X SMA). PISA di dalamnya terdapat pengukuran kemampuan literasi matematika yang membutuhkan kemampuan berpikir kreatif matematis dalam menyelesaikannya (OECD, 2013). Pada pencapaian tersebut, kemampuan matematika siswa Indonesia mendapatkan nilai rata-rata sebesar 386 pada tahun 2015. Indonesia naik sebesar 51 poin dibandingkan dengan tes sebelumnya yaitu tahun 2012 , sehingga hal ini menjadikan Indonesia naik peringkat. Pada kemampuan membaca, pada tahun 2015 siswa Indonesia mendapatkan skor rata-rata sebesar 397 sehingga hanya naik 2 poin tahun 2012. Selanjutnya kemampuan sains siswa Indonesia pada tahun 2015 sebesar 403 dengan kenaikan sebesar 21 poin dibandingkan dengan tahun 2012 (lihat Gambar 1).

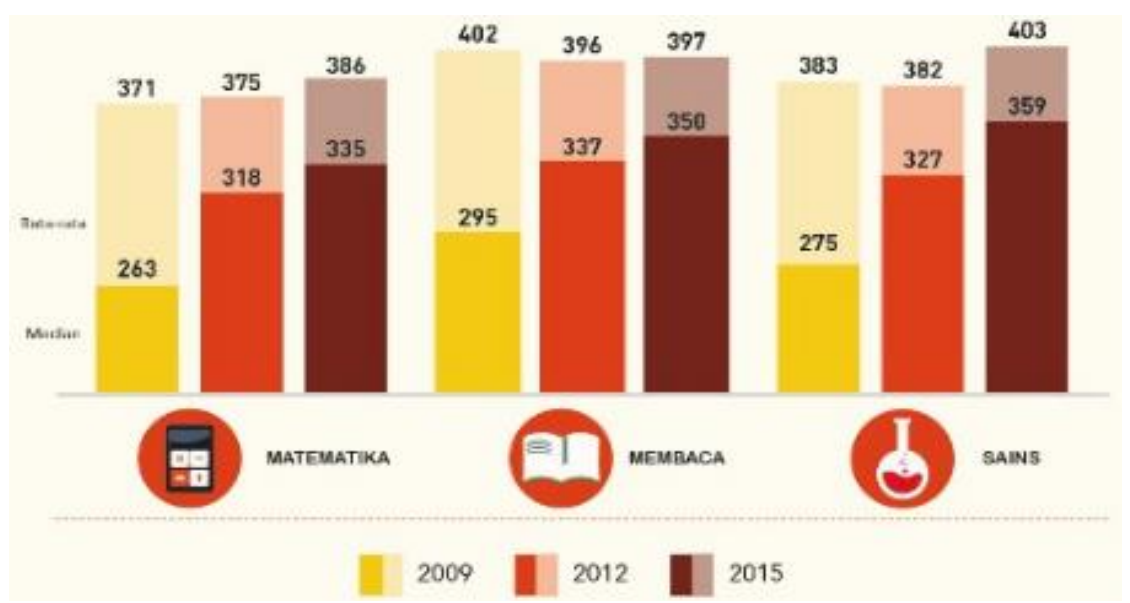

Gambar 1. Tren pencapaian Indonesia di PISA 2009-2015 (Kemendikbud, 2016b)

PISA sebagai tes matematika untuk skala Internasional menjadi salah satu tolak ukur bagi guru-guru dan berbagai elemen pendidikan untuk meningkatkannya menjadi lebih baik lagi pada tahun 2018. Di tahun 2012 pada level nilai tertinggi yang diperoleh siswa Indonesia pun masih masuk dalam kategori di bawah rata-rata level internasional. Indonesia sebagai negara yang mengikuti PISA sudah 15 tahun terakhir dengan data yang tidak memuaskan. PISA memiliki enam level tingkatan soal. Siswa Indonesia sebagian besar menjawab soal pada level 1 dan 2 .

Indonesia merupakan salah satu negara PISA peserta yang telah bergabung sejak tahun 2000. Dari tes yang diadakan tiga tahun sekali tersebut Indonesia telah mengikutinya dari tahun 2000 sampai dengan 2018 yang terbaru. Melalui PISA tersebut, kemampuan siswa Indonesia diukur berdasarkan pengetahuan dan keterampilan yang penting dalam berpartisipasi dalam masyarakat modern dan hal ini terfokus pada mengukur kemampuan membaca, matematika, dan sains. PISA memiliki framework pengembangan penilaian yang menggunakan istilah literasi matematika. Literasi matematika sangat menekankan pada kebutuhan untuk mengembangkan kapasitas siswa untuk menggunakan matematika dalam suatu konteks. Menurut OECD (2013), struktur kerangka matematika PISA dapat dicirikan oleh representasi matematis: Mathematical Literacy + $3 \mathrm{C}$ (content, context, and competency). Misalkan masalah terjadi dalam situasi di dunia nyata, situasi ini merupakan konteks dalam tugas matematika. Dalam menggunakan matematika untuk memecahkan masalah, siswa harus memiliki tingkat penguasaan atas konten matematika yang relevan.

Pada hasil PISA 2015 juga didapatkan persentase peserta sampel yang mengikuti tersebut yang terdiri dari kelas X SMA dan kelas IX SMP. Sampel yang diambil pada PISA diketahui mensyaratkan umur 15 tahun sehingga tidak dapat dipungkiri bahwa kedua jenjang pendidikan ini masuk dalam kategori populasi yang akan diambil. 
Namun hal mengejutkan terjadi, pada hasil PISA 2015 selain mengalami kenaikan yang baik, tetapi juga didapatkan hal lain sebagaimana ditunjukkan pada Gambar 2. Hasil PISA pada kemampuan sains menunjukkan bahwa siswa kelas X SMA memiliki skor yang lebih baik dibandingkan siswa kelas IX SMP, sehingga ada kemungkinan bahwa siswa kelas X SMA pada kemampuan matematika juga dapat lebih tinggi skornya dibandingkan siswa kelas XI SMP.

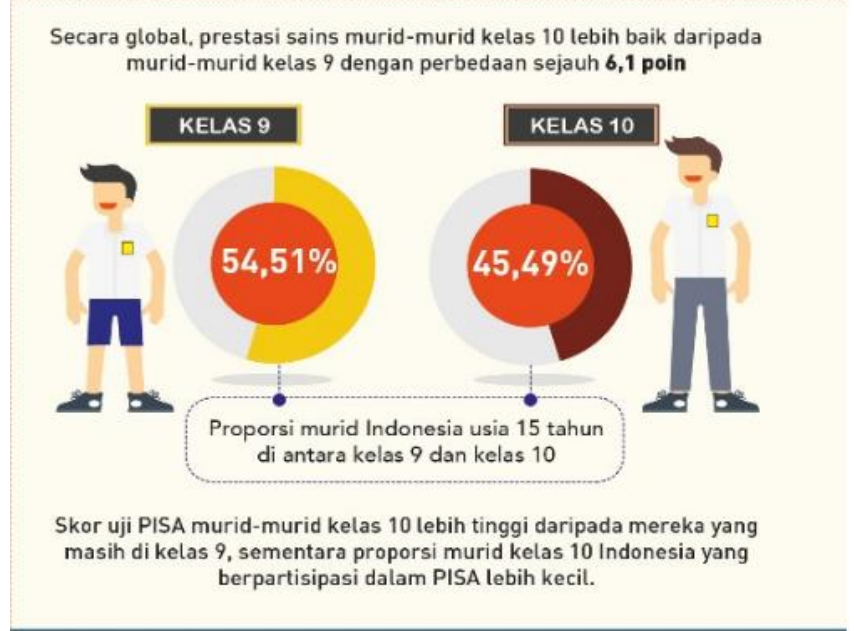

Gambar 2. Persentase siswa SMA dan SMP pada PISA (Kemendikbud, 2016b)

PISA dan open-ended memiliki hubungan yang erat dalam hal mengembangkan kemampuan berpikir kreatif matematis. Dalam PISA terdapat soal-soal yang terbuka jawabannya sehingga memungkinkan siswa berpikir terbuka pula. Apabila siswa Indonesia memiliki nilai PISA yang relatif rendah, kemungkinan besar kemampuan berpikir kreatif matematis siswa pun ikut rendah. Soal open-ended yang merupakan soal kontekstual menjadikannya menarik untuk dikaji secara lebih mendalam terlebih untuk soal open-ended dalam soal-soal PISA. Meskipun beberapa penelitian tentang berpikir kreatif yang menggunakan soal open-ended sudah dilakukan (misalnya, Damayanti \& Sumardi, 2018; Happy \& Widjajanti, 2014; Hidayat \& Widjajanti, 2018; Kwon et al., 2006; Miatun \& Nurafni, 2019; Sariningsih \& Herdiman, 2017), belum banyak penelitian yang menggunakan soal open-ended jenis PISA. Oleh karena itu, penelitian ini dilakukan untuk mendeskripsikan kemampuan berpikir kreatif matematis siswa dalam penyelesaian soal open-ended jenis PISA dengan fokus pada level sekolah.

\section{METODE}

Penelitian ini adalah penelitian survei yang dilaksanakan selama bulan Maret sampai April 2017 di 10 sekolah tingkat SMA di Kabupaten Lampung Timur. Populasi pada penelitian ini adalah 4.720 siswa kelas X SMA dari 44 SMA negeri dan swasta di Kabupaten Lampung Timur, Provinsi Lampung. Dari populasi tersebut, terpilih 260 siswa untuk menjadi sampel penelitian. Teknik pengambilan sampel dilakukan dalam tiga tahap yaitu, (1) stratified sampling untuk menentukan strata sekolah berdasarkan akreditasi sekolah menjadi tiga kategori, yaitu strata tinggi untuk sekolah berakreditasi A, strata sedang untuk sekolah berakreditasi B, dan strata rendah untuk sekolah berakreditasi C; (2) random sampling untukmendapatkan berapa banyak sekolah yang digunakan dalam penelitian dengan memperhatikan bahwa terdapat 44 sekolah dengan tiga kategori akreditasi sekolah, yaitu 18 sekolah berakreditasi A, 14 sekolah berakreditasi B, dan 12 sekolah berakreditasi C, di mana sekolah-sekolah tersebut memiliki 20-40 siswa per kelasnya; dan (3) proportionate stratified random sampling pada setiap kategori/ strata, sehingga terpilih 10 sekolah yang terdiri atas 5 sekolah dengan akreditasi A, 3 sekolah akreditasi B, dan 2 sekolah dengan akreditasi $\mathrm{C}$.

\section{Prosedur Penelitian}

Prosedur penelitian terdiri atas beberapa tahap, yaitu (1) melaksanakan pra survei nilai PISA beberapa tahun terakhir yang dicapai Indonesia dan akreditasi sekolah yang bertujuan untuk mendapatkan informasi awal yang akan memberikan gambaran penelitian; (2) menentukan sampel penelitian yang sesuai; (3) melaksanakan penelitian, yaitu membagikan soal tes kemampuan berpikir kreatif matematis dengan soal open-ended jenis PISA yang telah divalidasi dan melakukan wawancara berdasarkan hasil dari tes kemampuan berpikir kreatif matematis; (4) mereduksi data hasil penelitian, yaitu mengoreksi hasil pengerjaan siswa pada penyelesaian soal open-ended jenis 
Evie Dwy Wahyu Arista, Ali Mahmudi

PISA dan melakukan analisis kemampuan berpikir kreatif matematis serta mereduksi beberapa data yang tidak sesuai; dan (5) menyusun laporan penelitian dengan mendeskripsikan data hasil tes kemampuan berpikir kreatif matematis berdasarkan level sekolah.

\section{Instrumen Pengumpulan Data}

Instrumen yang digunakan dalam penelitian ini adalah tes kemampuan berpikir kreatif matematis siswa dan wawancara mendalam terkait dengan kemampuan berpikir kreatif matematis. Adapun bentuk-bentuk instrumen dalam penelitian ini sebagai berikut. Pertama, tes kemampuan berpikir kreatif soal open-ended jenis PISA. Tes kemampuan berpikir kreatif soal open-ended jenis PISA merupakan tes yang digunakan untuk menganalisis kemampuan berpikir kreatif matematis. Tes dibuat dalam bentuk soal uraian yang terdiri atas enam butir soal yang ditentukan peneliti berdasarkan indikator soal yang rujuk pada jenis soal open-ended jenis PISA (lihat Tabel 1). Waktu pengerjaan tes tersebut adalah $2 \times 45$ menit, di mana guru dan peneliti bertindak sebagai pengawas selama pelaksanaan tes tersebut.

Tabel 1. Indikator tes kemampuan berpikir kreatif matematis menggunakan soal open-ended tipe PISA

\begin{tabular}{llllc}
\hline \multirow{2}{*}{ Open-ended } & \multicolumn{2}{c}{ PISA } & Berpikir kreatif matematis & $\begin{array}{c}\text { Jumlah } \\
\text { butir soal }\end{array}$ \\
\cline { 2 - 4 } Finding & Proses & Konten & Fluency, originality, elaboration & 1 \\
relations, & Employ & Uncertainty and data & Fluency, flexibility, originality, elaboration & 1 \\
classifying, & Interpret & Quantity & Fluency, flexibility, elaboration & 1 \\
measuring & Interpret & Uncertainty and data & Fluency, elaboration & 1 \\
& Employ & Space and shape & Fluency, flexibility, originality, elaboration & 1 \\
& Formulate & Space and shape & Fluency, flexibility, originality, elaboration & 1 \\
\hline
\end{tabular}

Kedua, wawancara yang dilakukan adalah wawancara mendalam kepada unit subjek penelitian yang memiliki kemampuan berpikir kreatif matematis. Wawancara dilakukan untuk mempertegas level kemampuan berpikir kreatif matematis yang dimilikinya dalam mengerjakan soal open-ended jenis PISA. Kegiatan ini dilakukan sesuai dengan pedoman wawancara namun tidak mengikat, sehingga pertanyaan dapat dikembangkan secara tidak terstruktur sesuai dengan jawaban lisan dan perilaku siswa saat diwawancara. Kriteria siswa yang dipilih untuk wawancara mendalam adalah siswa yang memiliki jawaban yang memenuhi kriteria berpikir kreatif matematis.

\section{Validitas dan Reliabilitas Instrumen}

Validitas instrumen perlu dibuktikan sebagai pertimbangan apakah instrumen yang dibuat layak digunakan untuk mengukur kemampuan siswa atau tidak. Validitas suatu instrumen tes ditunjukkan dengan bukti validitas, di antaranya adalah validitas isi. Validitas isi merupakan bukti penting yang pertama dan utama bagi suatu instrumen tes (Allen \& Yen, 1979). Validitas dalam penelitian ini menggunakan validitas isi dengan expert judgment, yaitu dua orang dosen Jurusan Pendidikan Matematika, Universitas Negeri Yogyakarta dan satu orang ahli dari P4TK (Pusat Pengembangan dan Pemberdayaan Pendidik dan Tenaga Kependidikan). Tujuan validasi ini adalah untuk mendapatkan masukan mengenai kekurangan instrumen tes kemampuan berpikir kreatif matematis berupa tes pilihan uraian yang berjumlah enam butir soal. Data validasi dari expert judgment terhadap kualitas instrumen tes kemampuan berpikir kreatif matematis yang ditinjau dari lima aspek penilaian (kesesuaian tujuan/indikator dengan soal, kerincian dan kejelasan soal, penggunaan bahasa, bahasa yang mudah, dan kesederhanaan kalimat) menunjukkan bahwa hasil rata-rata penilaian tersebut masuk ke dalam kategori baik.

Setelah instrumen tes kemampuan berpikir kreatif matematis terbukti valid dalam hal validitas isi, instrumen tersebut diujicobakan untuk mengestimasi koefisien reliabilitasnya. Estimasi koefisien reliabilitas dilakukan dengan menggunakan rumus Cronbach's alpha. Hasil estimasi menunjukkan bahwa koefisien reliabilitas Cronbach's alpha sebesar 0,727. Karena standar koefisien reliabilitas instrumen tes berbentuk soal terbuka (open-ended) menurut Nitko dan Brookhart (2011) adalah pada rentang 0,65 sampai 0,80, berarti dapat dikatakan bahwa instrumen tes yang digunakan dalam penelitian ini bersifat reliabel. 
Tabel 2. Kategori kemampuan berpikir kreatif matematis siswa

\begin{tabular}{ll}
\hline Rentang skor & Kategori \\
\hline $0-6$ & Sangat Kurang \\
$7-10$ & Kurang \\
$11-14$ & Cukup \\
$15-18$ & Baik \\
$19-24$ & Sangat Baik \\
\hline
\end{tabular}

\section{Teknik Analisis Data}

Data yang diperoleh dalam penelitian ini yang berupa skor tes kemampuan berpikir kreatif matematis dengan soal open-ended jenis PISA dianalisis secara deskriptif. Data skor tes kemampuan berpikir kreatif matematis diperoleh berdasarkan kategori/bobot skor setiap soal dengan rentang skor 0 sampai 4 yang telah disesuaikan dengan kriteria menurut indikator kemampuan berpikir kreatif matematis. Berdasarkan penskoran ini, skor minimum dan skor maksimum yang dapat diperoleh siswa secara berturut-turut adalah 0 dan 24 . Skor ini kemudian dikategorikan menjadi lima kategori yang merepresentasikan kemampuan berpikir kreatif matematis siswa (lihat Tabel 2). Data yang diperoleh kemudian dideskripsikan berdasarkan data secara keseluruhan, level sekolah, dan indikator/aspek kemampuan berpikir kreatif matematis.

\section{HASIL PENELITIAN}

\section{Deskripsi Kemampuan Berpikir Kreatif Matematis Secara Keseluruhan}

Tes kemampuan berpikir kreatif matematis siswa terdiri atas enam soal berbentuk uraian (constructed response) yang masing-masing mencakup empat aspek kemampuan yang diukur, yaitu fluency, flexibility, originality, dan elaboration. Dari tes ini dapat diperoleh deskripsi kemampuan berpikir kreatif matematis siswa secara keseluruhan dari kategori sangat kurang sampai dengan kategori sangat baik (lihat Tabel 3).

Tabel 3. Kemampuan berpikir kreatif matematis siswa secara keseluruhan

\begin{tabular}{llrc}
\hline Rentang skor & Kategori & Jumlah siswa $(\%)$ & Rata-rata \\
\hline $0-6$ & Sangat Kurang & $22(8,46)$ & 10,53 \\
$7-10$ & Kurang & $80(30,77)$ & \\
$11-14$ & Cukup & $117(45,00)$ & \\
$15-18$ & Baik & $35(13,46)$ & \\
$19-24$ & Sangat Baik & $6(2,31)$ & \\
\hline
\end{tabular}

Tabel 3 menunjukkan bahwa sebagian besar siswa sudah memiliki kemampuan berpikir kreatif matematis pada kategori cukup. Lebih lanjut, karena rata-rata skor kemampuan berpikir kreatif matematis siswa lebih dari 10, berarti dapat dikatakan bahwa secara keseluruhan kemampuan berpikir kreatif matematis siswa masih berada pada kategori cukup.

\section{Deskripsi Kemampuan Berpikir Kreatif Matematis Berdasarkan Level Sekolah}

Kemampuan berpikir kreatif matematis siswa dalam menyelesaikan soal open-ended jenis PISA merupakan fokus dari penelitian ini. Oleh karena itu, 10 SMA yang terdiri atas 5 sekolah level tinggi dengan 157 siswa kelas X, 3 sekolah level sedang dengan 59 siswa kelas $X$, dan 2 sekolah level rendah dengan 44 siswa kelas $X$ terlibat dalam penelitian ini. Deskripsi kemampuan berpikir kreatif matematis dari 260 siswa kelas X yang tersebar di 10 SMA yang dikelompokkan berdasarkan level sekolah disajikan dalam Tabel 4. Berdasarkan Tabel 4, sebagian besar siswa, baik dari level sekolah tinggi, sedang, maupun rendah, memiliki kemampuan berpikir kreatif matematis pada kategori cukup. Kategori kemampuan berpikir kreatif matematis sangat baik menjadi kategori dengan persentase jumlah siswa terkecil dari lima kategori yang ada pada semua level sekolah. Lebih lanjut, dari Tabel 4 juga dapat diperoleh informasi bahwa level sekolah berbanding lurus dengan persentase jumlah siswa dengan kategori kemampuan berpikir kreatif matematis cukup, namun berbanding terbalik dengan persentase jumlah siswa dengan kategori kemampuan berpikir kreatif matematis sangat kurang dan baik. Kategori kemampuan berpikir matematis sangat baik hanya ditemukan pada sekolah level tinggi. 
PYTHAGORAS: Jurnal Pendidikan Matematika, 15 (1), 2020 - 93

Evie Dwy Wahyu Arista, Ali Mahmudi

Tabel 4. Kemampuan berpikir kreatif matematis siswa berdasarkan level sekolah

\begin{tabular}{lrrr}
\hline \multirow{2}{*}{ Kategori } & \multicolumn{3}{c}{ Level sekolah } \\
\cline { 2 - 4 } & Tinggi $(\%)$ & Sedang $(\%)$ & Rendah $(\%)$ \\
\hline Sangat Kurang & $10(6,37)$ & $6(10,17)$ & $6(13,64)$ \\
Kurang & $48(30,57)$ & $18(30,51)$ & $14(31,82)$ \\
Cukup & $73(46,50)$ & $27(45,76)$ & $17(38,64)$ \\
Baik & $20(12,74)$ & $8(13,56)$ & $7(15,90)$ \\
Sangat Baik & $6(3,82)$ & $0(0,00)$ & $0(0,00)$ \\
\hline
\end{tabular}

Hasil analisis terhadap data kemampuan berpikir kreatif matematis siswa berdasarkan level sekolah juga menunjukkan bahwa rata-rata skor kemampuan berpikir kreatif matematis siswa dari sekolah level tinggi, sedang, dan rendah secara berturut-turut adalah 11,10 , dan 11 . Ini berarti kemampuan berpikir kreatif matematis siswa dalam penyelesaian soal open-ended jenis PISA pada sekolah level tinggi dan rendah masuk ke dalam kategori cukup, sedangkan pada sekolah level sedang masuk ke dalam kategori kurang.

\section{Deskripsi Kemampuan Siswa Berdasarkan Indikator Kemampuan Berpikir Kreatif Matematis}

Untuk mendapatkan gambaran secara mendalam terhadap kemampuan berpikir kreatif matematis siswa, data skor kemampuan tersebut juga dideskripsikan berdasarkan indikator-indikatornya, yaitu fluency, flexibility, originality, dan elaboration (lihat Tabel 5).

Tabel 5. Persentase skor berdasarkan indikator kemampuan berpikir kreatif matematis

\begin{tabular}{|c|c|c|c|c|c|c|c|}
\hline \multirow{2}{*}{ Indikator } & \multicolumn{6}{|c|}{ Soal } & \multirow{2}{*}{ Rata-rata } \\
\hline & 1 & 2 & 3 & 4 & 5 & 6 & \\
\hline Fluency & 72,41 & 49,43 & 51,34 & 50,57 & 31,03 & 59,39 & 52,36 \\
\hline Flexibility & 59,77 & 29,50 & 36,59 & - & 28,74 & 36,40 & 38,20 \\
\hline Originality & 35,63 & 19,54 & - & - & 22,99 & 18,39 & 24,14 \\
\hline Elaboration & 60,54 & 31,42 & 27,20 & 43,30 & 27,20 & 37,93 & 37,93 \\
\hline
\end{tabular}

Tabel 5 menunjukkan bahwa pada soal nomor 1, 2, 5, dan 6, originality merupakan indikator dengan persentase terkecil dari empat indikator kemampuan berpikir kreatif matematis yang ada. Selain itu, originality tersebut juga merupakan indikator dengan rata-rata persentase terkecil dibandingkan tiga indikator lainnya. Ini berarti kemampuan originality perlu mendapatkan perhatian lebih dalam usaha memfasilitasi pengembangan kemampuan berpikir kreatif matematis siswa. Adapun fluency dalam hal ini menjadi indikator dengan persentase terbesar di antara tiga indikator lainnya pada keenam soal tes yang ada dan begitu juga ketika ditinjau berdasarkan rata-ratanya.

\section{PEMBAHASAN}

Kemampuan berpikir kreatif matematis merupakan kemampuan yang terdiri atas aspek fluency, flexibility, originality, dan elaboration. Keempat aspek kemampuan tersebut terdapat pada siswa dengan level sekolah tinggi, sedang, dan rendah. Sekolah sampel pada penelitian ini menggunakan kurikulum yang berbeda. Kurikulum 2006 menjadi mayoritas yang dipakai pada sekolah-sekolah tersebut dan beberapa di antaranya menggunakan Kurikulum 2013. Hal ini disebabkan banyak sekolah belum siap dengan pengaplikasian Kurikulum 2013 dari segi guru, fasilitas, dan sosialisasi. Kenyataan di sekolah-sekolah dengan Kurikulum 2013 terdapat lebih banyak siswa yang memiliki kemampuan berpikir kreatif yang dikategorikan baik dibandingkan dengan siswa pada sekolah dengan Kurikulum 2006. Hal ini dapat menjadikan Kurikulum 2013 sebagai kurikulum yang mampu menjawab tantangan dunia kerja dan masa depan, yaitu tentang kreativitas pada pendidikan Indonesia. Dengan kata lain, Kurikulum 2013 dapat lebih baik dalam memfasilitasi kemampuan berpikir kreatif matematis siswa.

Hasil penelitian ini mengungkapkan bahwa rata-rata persentase skor kemampuan berpikir kreatif matematis yang dicapai siswa pada aspek fluency sebesar 52,36\%. Aspek fluency dirasakan baik karena sebagian besar siswa mampu menjelaskan permasalahan dan mencetuskan banyak gagasan, jawaban, dan penyelesaian masalah. Dalam hal ini, didapatkan hasil pengerjaan siswa yang masuk ke dalam aspek fluency berupa kelancaran dalam berpikir dan menuangkan ide-ide dalam menyelesaikan soal (lihat Gambar 3). Gambar 3 menunjukkan hasil pekerjaan salah satu siswa (SLA012) dari sekolah level tinggi dalam penyelesaian soal nomor 1. Pada hasil pekerjaan 
tersebut, siswa memiliki dua hasil yang berbeda apabila yang digunakan bentuk diskon yang berbeda. Siswa tersebut sudah memahami permasalahan pada soal nomor 1 yang ditunjukkan dengan siswa tersebut memiliki ide bahwa apabila uang tersebut tersisa maka akan dibelikan barang kembali sehingga uang yang tersisa akan sedikit. Namun gagasan atau jawaban yang diberikan siswa belum lengkap atau masih keliru. Berdasarkan hasil ini dapat disimpulkan bahwa kemampuan berpikir kreatif matematis siswa khususnya pada aspek fluency sudah baik. Siswa sangat baik dalam menuangkan tiap ide dan dituliskan secara baik dan benar. Pada tulisan jawaban, siswa juga menuliskan hal yang diketahui dan ditanyakan dalam soal yang kemungkinan siswa lain tidak menuliskannya. Dari berbagai ide yang dituangkan siswa dalam jawaban tersebut, dapat dilihat bahwa siswa tersebut mulai berpikir kreatif dengan beberapa jawaban yang dituliskan. Siswa lain hanya menuliskan satu jenis jawaban tetapi siswa ini menuliskan beberapa alternatif jawaban yang menurutnya benar.

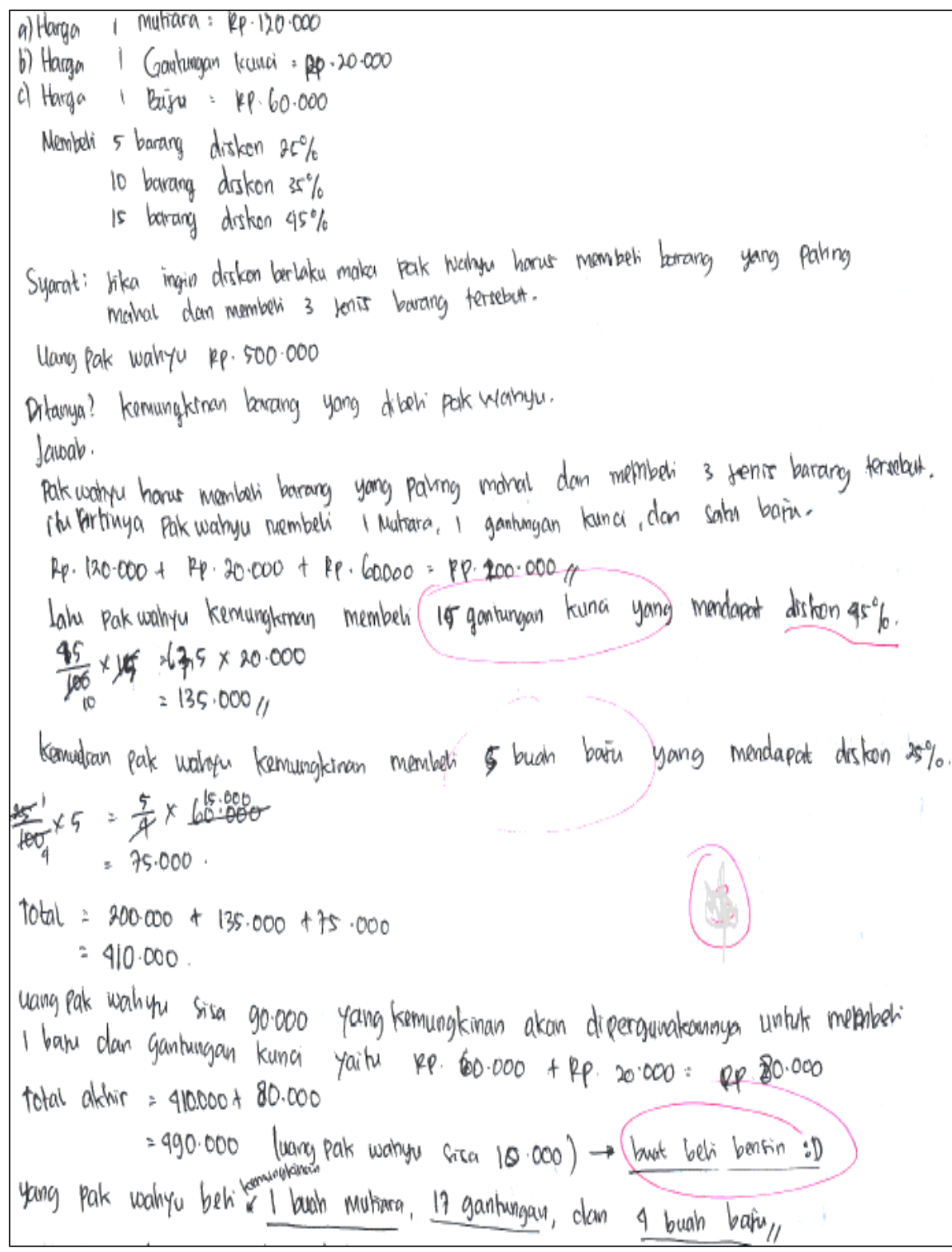

Gambar 3. Hasil pekerjaan siswa dari sekolah level tinggi dalam penyelesaian soal nomor 1

Berdasarkan hasil penelitian, rata-rata persentase skor kemampuan berpikir kreatif matematis pada aspek flexibility sebesar 38,20 \%. Pada aspek flexibility ini juga termasuk cukup baik. Hal ini disebabkan karena sebagian siswa mampu menghasilkan gagasan, jawaban, atau pertanyaan yang bervariasi. Siswa juga dapat melihat masalah dari sudut pandang yang berbeda, mencari banyak alternatif yang berbeda, serta mampu mengubah cara pendekatan penyelesaian masalah yang ada. Gambar 4 merupakan pekerjaan salah satu siswa (SLA027) dengan kemampuan berpikir kreatif matematis yang masuk dalam kategori baik dari sekolah level tinggi dalam penye- 
lesaian soal nomor 6 . Soal nomor 6 berkaitan dengan masalah konkret pengiriman barang sehari-hari. Beberapa siswa yang menjawab soal ini kurang peka dengan informasi terkait netto yang diberikan secara tersurat di dalam soal. Namun siswa dari sekolah level tinggi ini mampu mengetahui bahwa informasi terkait netto tersebut ada dalam soal. Walaupun siswa ini sedikit kesulitan dalam mengklasifikasikan masalah dari sudut yang berbeda dan memecahkan soal yang diberikan, tetapi jawaban yang diberikan benar dan dengan demikian siswa tersebut mampu memecahkan masalah tersebut dengan baik.

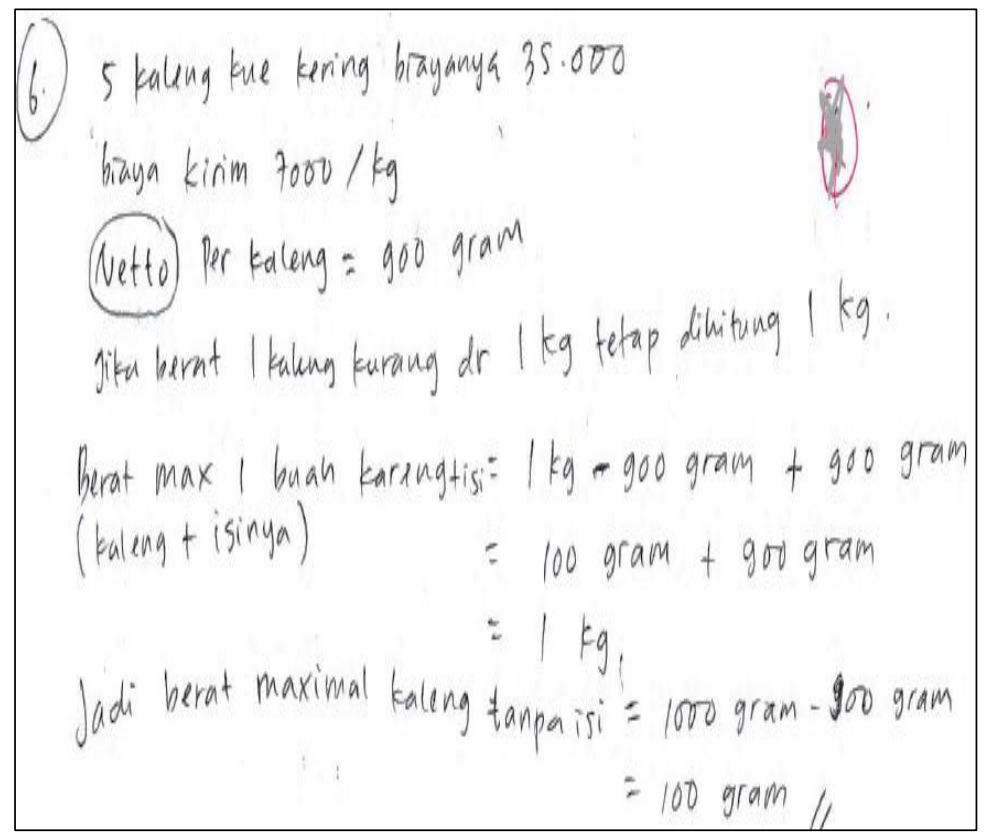

Gambar 4. Hasil pekerjaan siswa dari sekolah level tinggi dalam penyelesaian soal nomor 6

Hasil penelitian ini menunjukkan bahwa rata-rata persentase skor kemampuan berpikir kreatif matematis pada aspek originality sebesar $24,12 \%$ dan menjadikan capaian pada aspek ini terendah di antara empat aspek yang ada. Rata-rata ini memberikan informasi bahwa aspek originality masih tergolong kurang baik. Hasil ini sejalan dengan hasil penelitian Damayanti dan Sumardi (2018) yang menunjukkan bahwa capain pada aspek originality menjadi yang terendah dari tiga aspek kemampuan berpikir kreatif matematis yang ada, yaitu fluency, flexibility, dan originality. Rendahnya capaian siswa pada aspek originality pada penelitian ini disebabkan karena sebagian besar siswa masih kurang mampu dalam menggunakan strategi yang bersifat baru dan unik. Sebagian siswa lainnya tidak biasa untuk menyelesaikan masalah yang diberikan sehingga salah dalam mendapatkan solusi. Aspek originality yang masih termasuk kurang tersebut disebabkan oleh kurangnya kemampuan siswa dalam memahami dan merumuskan suatu masalah. Dari hasil wawancara yang dilakukan oleh peneliti kepada siswa dengan nilai tinggi, sedang, dan rendah pada tes kemampuan berpikir kreatif matematis terungkap bahwa tes dalam penelitian ini dirasa sulit bagi siswa yang mendapat nilai rendah. Adapun bagi sebagian siswa yang mendapat nilai sedang dan tinggi, tes tersebut dirasa mudah. Tes yang ada dirasa sulit karena siswa kesulitan dalam mengklasifikasikan masalah dari sudut pandang yang berbeda, memecahkan suatu permasalahan, dan memberikan contoh atau pernyataan yang bersifat baru dan unik. Dari hal ini dapat diketahui bahwa kemampuan berpikir kreatif matematis siswa pada dasarnya memiliki keterkaitan dengan pengetahuan siswa terhadap perumusan masalah ataupun penyelesaian suatu masalah dalam matematika khususnya pada soal open-ended.

Gambar 5 merupakan hasil pekerjaan salah satu siswa dari sekolah level tinggi, di mana siswa tersebut memberikan ide baru dalam penyelesaian soal nomor 3, yaitu menghapus hanya sebagian dari folder yang berisi file dalam album musik yang disediakan. Ketika siswa yang lain langsung memberikan ide menghapus semua isi dalam sebuah album musik, siswa ini memberikan ide yang lain yang lebih baik. Berdasarkan wawancara yang telah dilakukan dengan siswa tersebut diperoleh informasi bahwa siswa tersebut tidak menghapus semua isi dalam sebuah album musik karena bisa jadi masih ada beberapa isi yang diperlukannya di kemudian hari. Informasi ini berdasarkan jawaban siswa dalam wawancara yang dilakukan, yaitu "kemungkinan dalam kenyataan saya tidak pernah menghapus satu album langsung Bu karena hal tersebut tidak mungkin dan mungkin saja ada beberapa yang masih diperlukan oleh saya." 


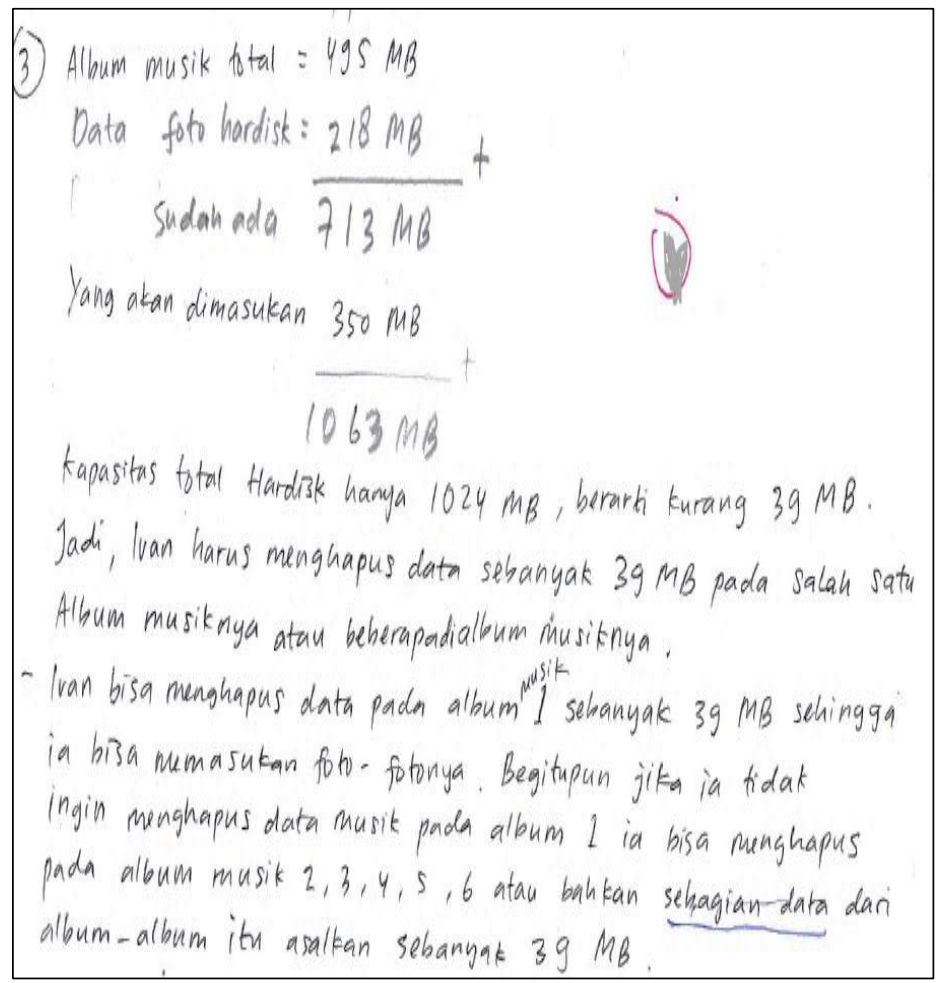

Gambar 5. Hasil pekerjaan siswa dari sekolah level tinggi dalam penyelesaian soal nomor 3

Rata-rata persentase skor kemampuan berpikir kreatif matematika pada aspek elaboration sebesar 24,12\%. Aspek elaboration sangat baik apabila digunakan dalam menjawab berbagai soal uraian baik yang open-ended maupun tidak. Elaboration juga dapat membantu siswa dalam mengingat dan memahami berbagai rumus yang dipakai dalam menjawab soal yang diberikan. Memecahkan suatu soal matematika bukan berati hanya menjawab tanpa ada proses di belakangnya. Dengan elaboration dalam soal ini menjadikan soal tersebut dijawab dengan terstruktur dan tidak salah dalam hal langkah pengerjaannya. Gambar 6 menunjukkan hasil pekerjaan salah satu siswa dari sekolah level tinggi dalam penyelesaian soal open-ended jenis PISA yang merefleksikan aspek elaboration. Berdasarkan Gambar 6, siswa sudah dapat memerinci bagian dari bata-bata yang seharusnya dihitung. Bata tersebut memiliki kemungkinan ukuran yang berbeda-beda. Siswa tersebut memisalkan bata-bata dengan bentuk kecil dan sedang serta panjang dengan ukuran yang diukur dengan satuan. Beberapa rincian data dari bata yang akan dihitung dituliskan dengan teliti, sehingga hal tersebut membuat perhitungan dari data tersebut benar. Meskipun siswa ini mendapatkan jawaban kurang tepat dan tidak lengkap karena jawaban yang dimaksud dari soal adalah dengan alas yang berbeda, siswa ini sudah memiliki kemampuan yang baik dalam menghitung secara tepat satuan dari bata-bata tersebut.

Secara keseluruhan, penelitian ini mendapatkan hasil bahwa kemampuan berpikir kreatif matematis siswa pada sekolah level tinggi dan rendah berada pada kategori cukup baik. Hasil ini cukup mengejutkan, sebab sekolah level tinggi diharapkan dapat memiliki siswa dengan kemampuan berpikir kreatif matematis yang tinggi. Bahkan kemampuan berpikir kreatif matematis siswa pada sekolah level sedang berada pada kategori kurang baik yang menjadikannya tidak lebih baik dibandingkan dengan siswa pada sekolah level rendah. Ini berarti level sekolah belum tentu menjamin tingkat kemampuan berpikir kreatif matematis siswa, terlebih sekolah level rendah yang mendapatkan akreditasi $\mathrm{C}$ pada penelitian bukan karena reputasi atau prestasi sekolah yang rendah, melainkan karena sekolah tersebut merupakan sekolah swasta baru.

Pada proses pengambilan data, tahap-tahap penelitian yang dilakukan sudah disesuaikan dengan keadaan sekolah masing-masing. Faktor waktu dalam mengerjakan tiap soal pada beberapa sekolah menjadi kendala utama bagi siswa, sehingga beberapa siswa tidak dapat menyelesaikan soal tersebut dengan baik. Berdasarkan keterangan guru mata pelajaran matematika di salah satu sekolah level tinggi, ketika penelitian ini dilaksanakan di sekolah tersebut, kegiatan pembelajaran di sekolah tersebut sedang kurang kondusif karena sedang banyak kegiatan sekolah. Selain itu, beberapa siswa tidak menjawab soal yang ada dengan teliti dan saksama. Banyaknya siswa yang terlambat masuk ke dalam kelas juga membuat siswa tersebut tidak dapat menyelesaikan soal yang 
ada pada tes yang diberikan. Hal-hal tersebut mengakibatkan hasil tes kemampuan berpikir kreatif matematis siswa di sekolah level tinggi tersebut kurang memuaskan.

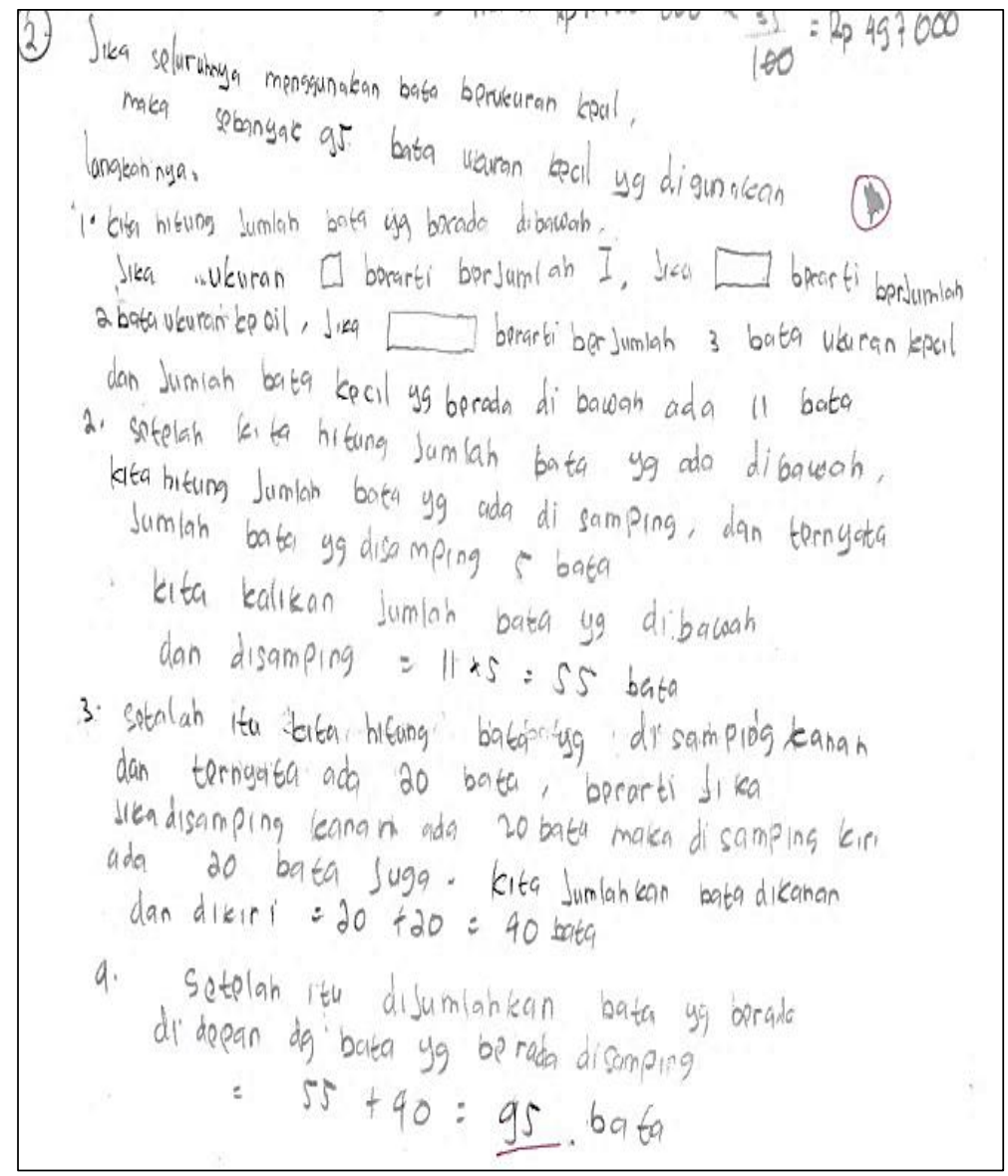

Gambar 6. Hasil pekerjaan siswa dari sekolah level tinggi dalam penyelesaian soal nomor 2

Hasil yang diperoleh pada penelitian ini mengungkapkan bahwa meskipun mayoritas siswa pada sekolah level tinggi, sedang, dan rendah memiliki kemampuan berpikir kreatif matematis yang cukup baik, siswa perlu lebih difasilitasi dalam mengembangkan kemampuannya tersebut khususnya dalam menyelesaikan soal open-ended jenis PISA agar menjadi lebih baik. Beberapa penelitian terdahulu telah merekomendasikan alternatif strategi yang dapat digunakan oleh guru untuk memfasilitasi pengembangan kemampuan berpikir kreatif matematis siswa, mulai dari menerapkan model pembelajaran tertentu (misalnya, Apino, 2016; Fitrianawati \& Hartono, 2016; Maskur et al., 2020; Rochani, 2016), membiasakan siswa untuk menyelesaikan masalah yang bersifat open-ended (misalnya, Kwon et al., 2006), hingga memanfaatkan teknologi pembelajaran (misalnya, Calder, 2018; Dhayanti et al., 2018; Saputra, 2016).

\section{SIMPULAN}

Penelitian ini menyimpulkan bahwa kemampuan berpikir kreatif matematis siswa dalam mengerjakan soal open-ended jenis PISA, baik pada sekolah level tinggi, sedang, maupun rendah, secara keseluruhan masih perlu ditingkatkan. Rata-rata kemampuan berpikir kreatif matematis siswa pada sekolah level tinggi masih berada pada kategori cukup, pada sekolah level sedang berada pada kategori kurang, sedangkan pada sekolah level rendah berada pada kategori cukup. Temuan penelitian ini perlu ditindaklanjuti oleh stakeholder pendidikan di Indonesia untuk perbaikan kualitas pembelajaran matematika di masa yang akan, khususnya dalam rangka memfasilitasi siswa mengembangkan keterampilan berpikir kreatif matematis maupun keterampilan-keterampilan lainnya yang relevan dengan era Revolusi Industri 4.0. Temuan penelitian ini juga dapat dijadikan dasar bagi peneliti lainnya untuk menyelidiki faktor-faktor yang mempengaruhi keterampilan berpikir kreatif maupun praktik-praktik pembelajaran yang dapat meningkatkan keterampilan tersebut. Selain itu, peneliti juga menyarankan agar peneliti lain dapat mereplikasi penelitian ini dengan melibatkan populasi dan sampel yang lebih luas. 


\section{DAFTAR PUSTAKA}

Allen, M. J., \& Yen, W. M. (1979). Introduction to measurement theory. Brooks/Cole.

Apino, E. (2016). Mengembangkan kreativitas siswa dalam pembelajaran matematika melalui pembelajaran creative problem solving. Prosiding Seminar Nasional Matematika dan Pendidikan Matematika, pp. 335-340. http://seminar.uny.ac.id/semnasmatematika/sites/seminar.uny.ac.id.semnasmatematika/files/PM-49.pdf

Brookhart, S. M. (2010). How to assess higher-order thinking skills in your classroom. ASCD.

Calder, N. (2018). Using Scratch to facilitate mathematical thinking. Waikato Journal of Education, 23(2), 43-58. https://doi.org/10.15663/wje.v23i2.654

Damayanti, H. T., \& Sumardi, S. (2018). Mathematical creative thinking ability of junior high school students in solving open-ended problem. Journal of Research and Advances in Mathematics Education, 3(1), 36-45. https://doi.org/10.23917/jramathedu.v3i1.5869

Dhayanti, D., Johar, R., \& Zubainur, C. M. (2018). Improving students' critical and creative thinking through realistic mathematics education using Geometer's Sketchpad. Journal of Research and Advances in Mathematics Education, 3(1), 25-35. https://doi.org/10.23917/jramathedu.v3i1.5618

Fard, A. E., Bahador, A., Moghadam, M. N., Rajabi, H., \& Moradi, A. N. (2014). The possible impact of problemsolving method of instruction on exceptional students' creativity. Journal of Education and Training Studies, 2(3), 60-68. https://doi.org/10.11114/jets.v2i3.342

Fitrianawati, M., \& Hartono, H. (2016). Perbandingan keefektifan PBL berseting TGT dan GI ditinjau dari prestasi belajar, kemampuan berpikir kreatif dan toleransi. Jurnal Riset Pendidikan Matematika, 3(1), 55-65. https://doi.org/10.21831/jrpm.v3i1.9684

Gomez, J. G. (2007). What do we know about creativity? The Journal of Effective Teaching, 7(1), 31-43. https://files.eric.ed.gov/fulltext/EJ1055657.pdf

Happy, N., \& Widjajanti, D. B. (2014). Keefektifan PBL ditinjau dari kemampuan berpikir kritis dan kreatif matematis, serta self-esteem siswa SMP. Jurnal Riset Pendidikan Matematika, 1(1), 48-57. https://doi.org/10.21831/jrpm.v1i1.2663

Hashimoto, Y. (1997). The methods of fostering creativity through mathematical problem solving. International Reviews on Mathematical Education, 29(3), 86-87. https://www.emis.de/journals/ZDM/zdm973a5.pdf

Hidayat, P. W., \& Widjajanti, D. B. (2018). Analisis kemampuan berpikir kreatif dan minat belajar siswa dalam mengerjakan soal open ended dengan pendekatan CTL. Pythagoras: Jurnal Pendidikan Matematika, 13(1), 63-75. https://doi.org/10.21831/pg.v13i1.21167

Kemendikbud. (2016a). Lampiran Peraturan Menteri Pendidikan dan Kebudayaan Nomor 22 Tahun 2016 tentang Standar Proses Pendidikan Dasar dan Menengah.

http://vervalsp.data.kemdikbud.go.id/prosespembelajaran/file/Permendikbud_Tahun2016_Nomor022_La mpiran.pdf

Kemendikbud. (2016b). Peringkat dan capaian PISA Indonesia mengalami peningkatan.

https://www.kemdikbud.go.id/main/blog/2016/12/peringkat-dan-capaian-pisa-indonesia-mengalamipeningkatan

Kitto, J., Lok, D., \& Rudowicz, E. (1994). Measuring creative thinking: An activity-based approach. Creativity Research Journal, 7(1), 59-69. https://doi.org/10.1080/10400419409534509

Kwon, O. N., Park, J. S., \& Park, J. H. (2006). Cultivating divergent thinking in mathematics through an open-ended approach. Asia Pacific Education Review, 7(1), 51-61. https://doi.org/10.1007/BF03036784

Mahmudi, A., \& Sumarmo, U. (2011). Pengaruh strategi Mathematical Habits of Mind (MHM) berbasis masalah terhadap kreativitas siswa. Cakrawala Pendidikan, 30(2), 216-229. https://doi.org/10.21831/cp.v0i2.4229 
Maskur, R., Sumarno, S., Rahmawati, Y., Pradana, K., Syazali, M., Septian, A., \& Palupi, E. K. (2020). The effectiveness of problem based learning and aptitude treatment interaction in improving mathematical creative thinking skills on Curriculum 2013. European Journal of Educational Research, 9(1), 375-383. https://doi.org/10.12973/eu-jer.9.1.375

Miatun, A., \& Nurafni, N. (2019). Profil kemampuan berpikir kreatif matematis ditinjau dari gaya kognitif reflective dan impulsive. Jurnal Riset Pendidikan Matematika, 6(2), 150-164. https://doi.org/10.21831/jrpm.v6i2.26094

Mihajlović, A., \& Dejić, M. (2015). Using open-ended problems and problem posing activities in elementary mathematics classroom. In F. M. Singer, F. Toader, \& C. Voica (Eds.), Proceedings of The 9th Mathematical Creativity and Giftedness International Conference (pp. 34-40). The International Group for Mathematical Creativity and Giftedness. https://www.mcg-9.net/pdfuri/MCG-9-Conference-proceedings.pdf\#page=36

Nitko, A. J., \& Brookhart, S. M. (2011). Educational assessment of students (6th ed.). Pearson.

Noer, S. H. (2011). Kemampuan berpikir kreatif matematis dan pembelajaran matematika berbasis masalah openended. JPM: Jurnal Pendidikan Matematika, 5(1), 104-111. https://doi.org/10.22342/jpm.5.1.824.

OECD. (2013). PISA 2012 assessment and analytical framework: Mathematics, reading, science, problem solving and financial literacy. OECD Publishing. https://doi.org/10.1787/9789264190511-en

Pelfrey, R. (2000). Open-ended questions for mathematics. https://www.uky.edu/OtherOrgs/ARSI/www.uky.edu/pub/arsi/openresponsequestions/mathorq.pdf

Rhosyida, N., \& Jailani, J. (2014). Pengembangan modul matematika SMK bidang seni, kerajinan, dan pariwisata berbasis open-ended problem sebagai implementasi KTSP. Jurnal Riset Pendidikan Matematika, 1(1), 35-47. https://doi.org/10.21831/jrpm.v1i1.2662

Rochani, S. (2016). Keefektifan pembelajaran matematika berbasis masalah dan penemuan terbimbing ditinjau dari hasil belajar kognitif kemampuan berpikir kreatif. Jurnal Riset Pendidikan Matematika, 3(2), 273-283. https://doi.org/10.21831/jrpm.v3i2.5722

Rochmad, R., Agoestanto, A., \& Kharis, M. (2018). Characteristic of critical and creative thinking of students of mathematics education study program. Journal of Physics: Conference Series, 983(1), 1-4. https://doi.org/10.1088/1742-6596/983/1/012076

Sanders, S. (2016). Critical and creative thinkers in mathematics classrooms. Journal of Student Engagement: Education Matters, 6(1), 19-27. https://ro.uow.edu.au/jseem/vol6/iss1/4

Saputra, P. R. (2016). Pembelajaran geometri berbantuan geogebra dan cabri ditinjau dari prestasi belajar, berpikir kreatif dan self-efficacy. Pythagoras: Jurnal Pendidikan Matematika, 11(1), 59-68. https://doi.org/10.21831/pg.v11i1.9680

Sariningsih, R., \& Herdiman, I. (2017). Mengembangkan kemampuan penalaran statistik dan berpikir kreatif matematis mahasiswa di Kota Cimahi melalui pendekatan open-ended. Jurnal Riset Pendidikan Matematika, 4(2), 239-246. https://doi.org/10.21831/jrpm.v4i2.16685

Sudarma, M. (2013). Mengembangkan keterampilan berpikir kreatif. Rajawali Pers.

Suharnan, S. (2005). Psikologi kognitif. Srikandi.

Trilling, B., \& Fadel, C. (2009). 21st century skills: Learning for life in our times. Jossey-Bass.

$\mathrm{Wu}, \mathrm{H}$. (1994). The role of open-ended problems in mathematics education. Journal of Mathematical Behavior, 13(1), 115-128. https://doi.org/10.1016/0732-3123(94)90044-2 